\title{
SEKOLAH TINGGI DESAIN DI PEKANBARU DENGAN PENDEKATAN DE STIJL
}

\author{
Fajria Madina*), Pedia Aldy, Muhd. Arief Al Husaini \\ *) Corresponding author email : fajria.madina@ student.unri.ac.id \\ Program Studi Arsitektur, Fakultas Teknik, Universitas Riau \\ Kampus Binawidya KM 12.5, Jl. HR. Soebrantas, Simpang Baru, Tampan, Pekanbaru, Riau
}

\author{
Article info \\ MODUL vol 20 no 01, issues period 2020 \\ Doi : : 10.14710/mdl.20.2.2020.111-119 \\ Received : 9 juli 2020 \\ Revised : 14 september 2020 \\ Accepted : 5 oktober 2020
}

\begin{abstract}
Abstrak
Pendidikan merupakan salah satu sumber penyedia SDM yang sangat dibutuhkan dalam dunia industri kreatif, salah satunya pendidikan desain. Hal yang sangat disayangkan apabila pendidikan ini tidak didukung sarana prasarana serta fasilitas yang memadai. Maka dari itu, dibutuhkan suatu wadah yang maтри menampung kegiatan tersebut. Wadah untuk menampung kegiatan pendidikan desain tersebut dapat berbentuk Sekolah Tinggi Desain. Seiring berjalannya waktu, pendidikan desain ini mengalami beberapa perkembangan yang dilahirkan dari kritik-kritik keras dari pada seniman dimasa lalu, yang melahirkan berbagai kelompok, salah satunya membentuk pendekatan De Stijl. Pembahasan ini bertujuan untuk mendeskripsikan beberapa alternative penerapan De Stijl pada perancangan Sekolah Tinggi Desain di Pekanbaru.
\end{abstract}

Kata Kunci: Sekolah Tinggi; Desain; De Stijl

\section{PENDAHULUAN}

Pendidikan desain di Indonesia merupakan salah satu dari 15 subsektor yang digolongkan dalam industri kreatif (Sachari, 2000). Industri kreatif merupakan penggerak penciptaan nilai ekonomi pada era ekonomi kreatif. Dalam hal ini, diperlukan upaya dalam meningkatkan kualitas dan kuantitas pendidikan desain sebagai salah satu penyedia SDM dalam industri kreatif. Upaya dalam meningkatkan kualitas dan kuantitas pendidikan desain dapat dilakukan dengan beberapa strategi, diantaranya dengan mendorong pihak swasta untuk mengembangkan lembaga pendidikan desain dalam bentuk perguruan tinggi; meningkatkan kualitas serta tata cara perizinan pembentukan pendidikan desain yang sesuai dengan standar prosedur dan peraturan yang berlaku. Meningkatkan kualitas tenaga kependidikan dan metode pengajaran, dengan menumbuhkan kreativitas, penguasaan iptek dan pola pikir desain; serta meningkatkan kualitas sarana dan prasarana pendidikan desain, juga termasuk dalam strategi meningkatkan kualitas dan kuantitas pendidikan desain. Upaya dalam meningkatkan kualitas dan kuantitas pendidikan ini tidak akan tercapai apabila tidak terdapat wadah yang dapat menampung pendidikan desain tersebut, sehingga diperlukanlah pembentukan Sekolah Tinggi Desain.

Pembentukan Sekolah Tinggi Desain sudah terdapat di beberapa tempat di Indonesia. Akan tetapi, Sekolah Tinggi Desain ini belum ada terbentuk di Provinsi Riau. Dari 25 Sekolah Tinggi di Riau, tidak ada satupun yang dibangun dalam bentuk Sekolah Tinggi Desain (Kemenristekdikti, 2018). Dikarenakan hal tersebut, diperlukan perancangan Sekolah Tinggi Desain di Pekanbaru.

Lingkup pendidikan desain ini tidak memiliki batas yang pasti. Desain melingkupi semua aspek yang berkaitan dengan kreatifitas dan imajinasi manusia. Akan tetapi, di Indonesia pendidikan desain secara praktis dapat dikelompokkan menjadi tiga bagian besar, yang terdiri dari Desain Produk Industri, Desain Interior, serta Desain Grafis/Desain Komunikasi Visual (Sachari, 2000). Dalam hal ini, ketiga pendidikan desain ini tergabung dalam Sekolah Tinggi Desain di Pekanbaru yang akan dirancang.

Perkembangan pendidikan desain dapat dipergunakan dihampir setiap bidang keilmuan untuk kegiatan yang amat bervariasi. Seiring berjalannya waktu, pendidikan desain ini mengalami beberapa perkembangan yang dilahirkan dari kritik-kritik keras dari pada seniman dimasa lalu, yang melahirkan berbagai kelompok, salah satunya membentuk pendekatan De Stijl. Pendekatan De Stijl ini terbentuk dari pemberontakan pemahaman desain yang ada pada saat itu (tahun 1920). Pendekatan ini merupakan pendekatan yang menghindari segala sesuatu yang emosianal, dengan hanya menggunakan elemen geometric abstrak yang terukur, tertata apik dan bersih, yang dapat dilihat dalam bentuk garis vertical horizontal 
dengan warna primer (merah, kuning, biru) serta warna monokrom (hitam dan putih). Pendekatan De Stijl ini dapat dijadikan sebagai pedoman dalam mendesain dikarenakan pendekatan ini terdapat hal dasar yang perlukan dalam mendesain suatu rancangan. Oleh karena itu, perancangan Sekolah Tinggi Desain di Pekanbaru yang akan dilakukan menggunakan Pendekatan De Stijl, sehingga dalam hal ini, 'Sekolah Tinggi Desain di Pekanbaru dengan Pendekatan De Stijl' ditetapkan sebagai judul perancangan.

Adapun tujuan dari perancangan Sekolah Tinggi Desain di Pekanbaru dengan pendekatan De Stijl ini yaitu menyediakan wadah kegiatan pendidikan desain dalam bentuk Sekolah Tinggi Desain di Pekanbaru, dengan fasilitas pendidikan, fasilitas ruang publik, serta fasilitas hunian yang disesuaikan dengan standar sarana dan prasarana yang berlaku di Indonesia, khususnya di Kota Pekanbaru; serta merumuskan beberapa alternatif desain Sekolah Tinggi Desain yang sesuai dengan pendekatan De Stijl.

\section{Pendekatan De Stijl}

De Stijl atau dalam Bahasa Inggris 'the style' merupakan gerakan seni sekitar tahun 1917 (Schultz dalam Sachari, 1994). Dalam pengertian yang lebih dalam, istilah De Stijl mengacu pada pekerjaan yang dihasilkan oleh sekelompok seniman Belanda. "Kelompok De Stijl didirikan di Belanda pada tahun 1917, didedikasikan untuk sintesa seni, desain dan arsitektur." (Harrison, 2003). Dalam perkembangan seni bangunan, Gerrit Rietveld merupakan salah satu sosok yang berpengaruh di dalam De Stijl, dengan ide dan hasil karya seninya yang mengembangkan seni dua dimensi De Stijl, ke dalam hasil karya dimensi. Hasil karya Rietveld yang pertama adalah De rood-blauwe stoel dan salah satu hasil karya seni bangunan yang terkenal adalah Schröderhuis yang terletak di Utrecht.

\section{METODOLOGI}

\section{Strategi Perancangan}

Perancangan Sekolah Tinggi Desain dengan Pendekatan De Stijl ini memiliki beberapa strategi perancangan, diantaranya menentukan fungsi dan tema perancangan, lokasi perancangan, analisa perletakan dan orientasi, program ruang, konsep, penzoningan, penataan bentuk massa bangunan, lansekap, serta didapatlah bentuk hasil desain.

\section{Metode Perancangan}

Metode perancangan Sekolah Tinggi Desain di Pekanbaru ini yaitu merumuskan pendekatan De Stijl dan menyimulasikan beberapa kemungkinan desain pada rancangan Sekolah Tinggi Desain di Pekanbaru.

\section{Lokasi Perancangan}

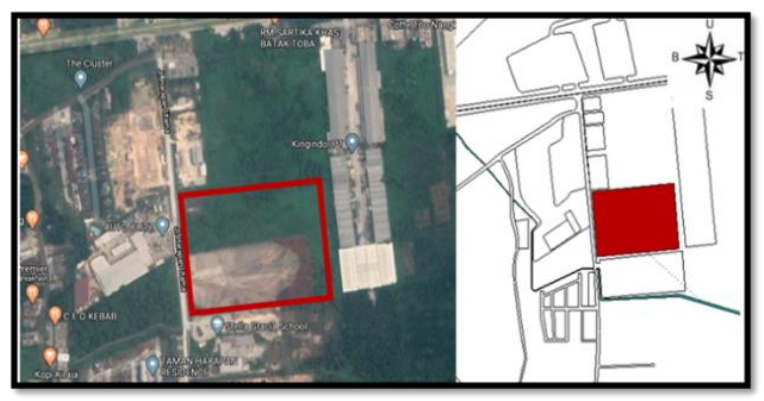

Gambar 1. Lokasi Tapak (Google Maps, 2020)

Lokasi site yang dipilih dalam perancangan Sekolah Tinggi Desain di Pekanbaru berada di Jalan Harapan Utama (Sebelah Stella Gracia School), Kecamatan Tampan, Pekanbaru, Riau. Lokasi yang memiliki lahan 3,91 Ha ini dipilih karena memiliki nilai tambah dalam perancangan Sekolah Tinggi Desain di Pekanbaru yang akan dirancang. Pemilihan ini dilakukan dengan beberapa pertimbangan, diantaranya lokasi yang strategis; berdekatan dengan bangunan yang memiliki fungsi pendidikan (Stella Gracia School), serta terdapat Universitas Pelita Indonesia yang sedang dalam proses pembangunan; berdekatan dengan halte busway, sehingga memudahkan akses pengguna transportasi umum; memiliki beberapa jalan alternatif; dipenuhi dengan vegetasi pada tapak; sangat dekat dengan area perumahan/hunian; memiliki lahan kosong yang masih sangat luas; serta telah memiliki jaringan listrik.

\section{HASIL DAN PEMBAHASAN}

\section{Konsep}

Ide dasar dari perancangan Sekolah Tinggi Desain ini, berawal dari pendekatan De Stijl yang telah ditetapkan sebelumnya sebagai tema bangunan. Konsep dasar dari De Stijl sendiri menuju kepada bentuk abstrak dan batas-batas yang jelas, langsung dari elemen-elemen bahasa visual yang menjadi konsekuensi, dalam mewujudkan konsep ke dalam bentuk seni termasuk Desain Grafis. Ekspresi visual hanya dibatasi oleh garisgaris lurus dan sudut-sudut. Garis-garis lurus dan sudutsudut tersebut tidak diterapkan secara 'sembarangan' pada desain, tetapi harus dengan proporsi yang tepat untuk mendapatkan estetika yang baik. Proporsi ini dapat dilakukan dengan menerapkan prinsip Golden Section, yaitu penggunaan Bilangan Fibonacci. 


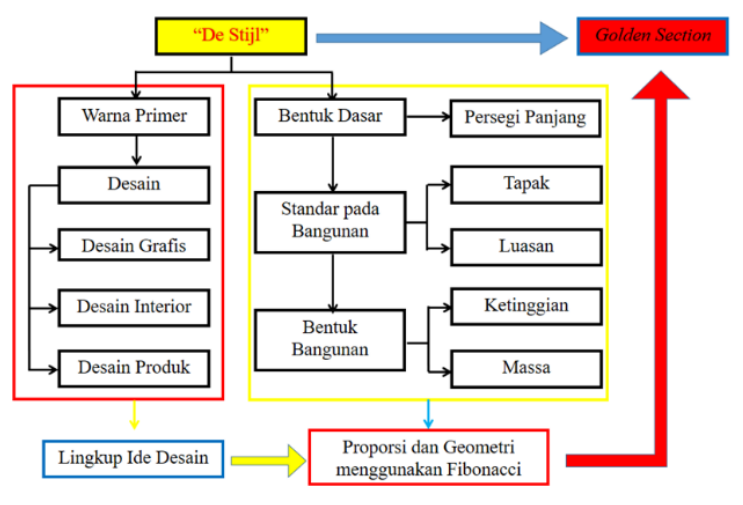

Gambar 2. Skema Konsep (Penulis, 2020)

Konsep Golden Section ini juga sesuai dengan penerapan pendekatan De Stijl, dikarenakan Piet Mondrian selaku salah satu tokoh yang menggunakan pendekatan De Stijl ini juga menerapkan Golden Section dalam setiap karyanya. Golden Section ini juga tidak terlepas kaitannya dari bentuk dasar yang merupakan bagian dari geometri.

Konsep-konsep tentang seni dan keindahan $D e$ Stijl diungkapkan dalam bentuk-bentuk murni, sehingga kemurnian menjadi penting pada pendekatan De Stijl ini. Penerapan kemurnian ini dapat ditunjukkan dengan penggunaan warna primer pada perancangan Sekolah Tinggi Desain, yang akan diterapkan pada desain Desain Grafis (bentuk massa serta fasad bangunan), interior, serta produk (furnitur) dalam bangunan. Penerapan ini ternyata sangat berkaitan dengan fungsi bangunan tersebut, yang merupakan wadah bagi pelajar yang ingin mengembangkan ilmunya dalam pendidikan Desain Grafis, desain interior, serta produk. Antara fungsi bangunan dengan penerapan tema sangat berkaitan, sehingga dapat dikatakan selaras atau harmoni. Keselerasan fungsi bangunan dengan penerapan tema menciptakan suatu proporsi, yang dapat dibentuk dalam Golden Section. Dari penjelasan ide desain ini, dapat disimpulkan konsep untuk perancangan Sekolah Tinggi Desain di Pekanbaru ini yaitu "Golden Section".

Kemudian dilakukanlah transfromasi desain, yang dimulai dari proses bentukan tapak, yang memiliki bentuk dasar persegi panjang dengan ukuran lahan $170 \mathrm{x}$ $230 \mathrm{~m}^{2}$. Persegi panjang tersebut merupakan bagian dari geometri, sesuai dengan prinsip De Stijl yaitu penggunaan bentuk-bentuk geometris.

Prinsip De Stijl ini dapat direalisasikan pada konsep tapak diantaranya pada vegetasi, sirkulasi kendaraan, maupun sirkulasi pejalan kaki. Pembentukan konsep tapak ini ditujukan untuk menentukan zonasi perancangan Sekolah Tinggi Desain, dengan melakukan proses transformasi desain pada tapak (lihat Gambar 3). Kemudian dilakukanlah penyesuaian konsep pada tapak (lihat Gambar 4).

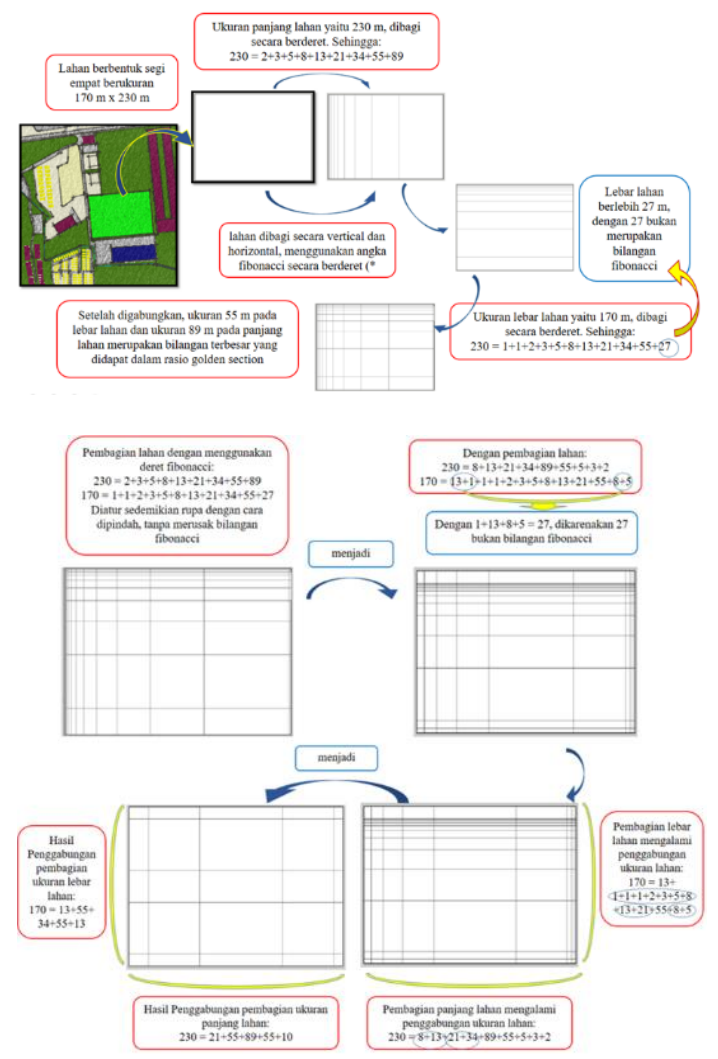

Gambar 3. Transformasi Bentuk Tapak (Penulis, 2020)

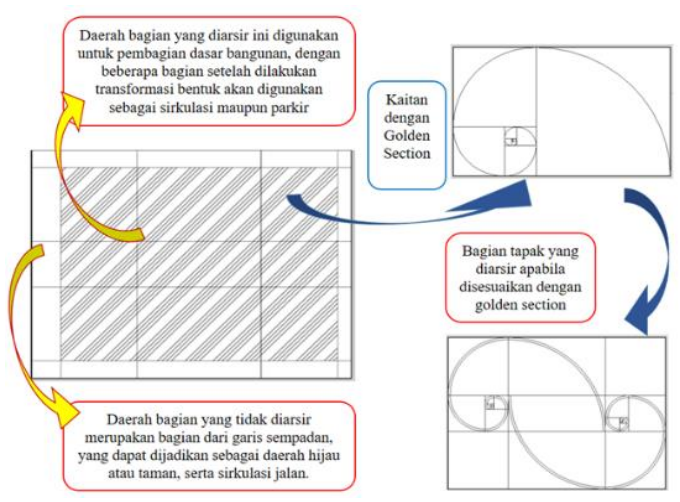

Gambar 4. Penyesuaian Konsep (Penulis, 2020)

Setelah dilakukan penyesuaian konsep Golden Section, pembagian tapak disesuaikan dengan prinsip $D e$ Stijl dengan membagi beberapa kelompok bangunan berdasarkan bentuk grid, yang dibagi menggunakan garis linear (vertical dan horizontal).

Beberapa kelompok bangunan pada perancangan Sekolah Tinggi Desain di Pekanbaru ini, dapat memunculkan beberapa alternatif desain pada konsep tapak. Beberapa alternatif desain ini, diantaranya:

A. Alternatif Desain 1 
Penggunaan warna primer seperti merah, kuning, dan biru (lihat Gambar 5) melambangkan kelompok bangunan publik, kelompok bangunan pendidikan sekolah tinggi desain, serta kelompok asrama mahasiswa dan area penunjang yang sesuai dengan prinsip De Stijl.

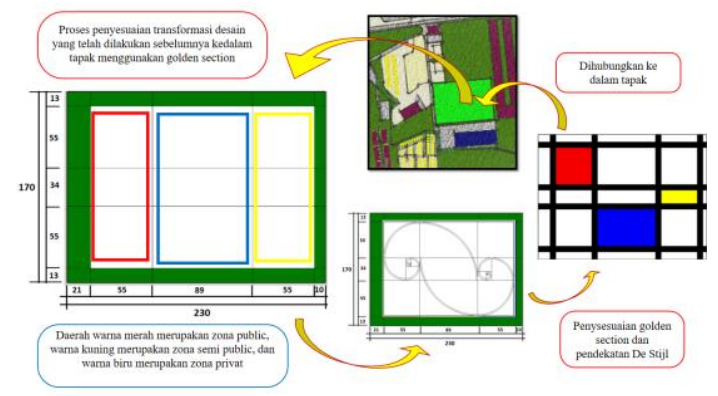

Gambar 5. Penyesuaian konsep tapak terhadap Pendekatan De Stijl Alternatif 1 (Penulis, 2020)

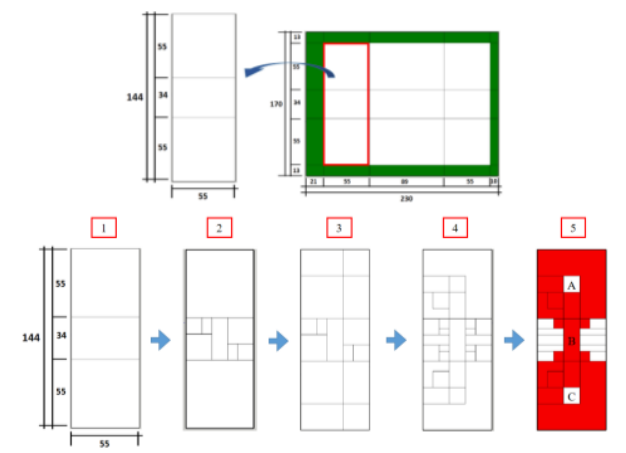

Gambar 6. Proses Transformasi Tapak Bangunan Publik pada Alternatif 1 (Penulis, 2020)

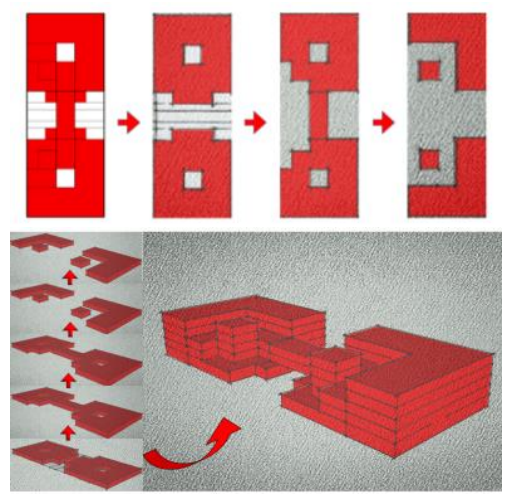

Gambar 7. Proses Bentukan Massa Bangunan Publik pada Alternatif 1 (Penulis, 2020)

Pada alternatif desain 1 ini, kelompok bangunan publik terletak pada bagian barat tapak, tepatnya berada didekat jalan utama agar memudahkan akses bagi pengguna publik. Kelompok bangunan pendidikan terletak pada daerah timur tapak. Kemudian dilakukan transformasi bentuk tapak sampai bentukan massa pada antar zonasi kelompok bangunan.
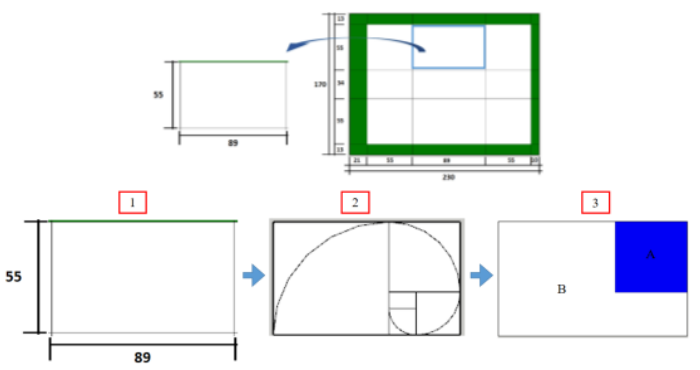

Gambar 8. Proses Transformasi Tapak Area Penunjang pada Alternatif 1 (Penulis, 2020)
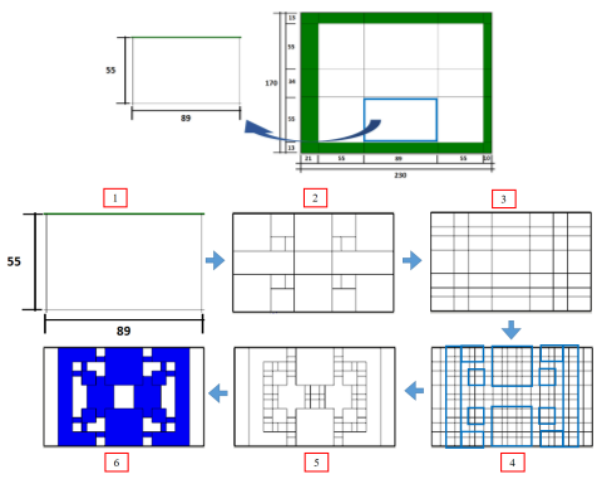

Gambar 9. Proses Transformasi Tapak Area Asrama Mahasiswa pada Alternatif 1 (Penulis, 2020)

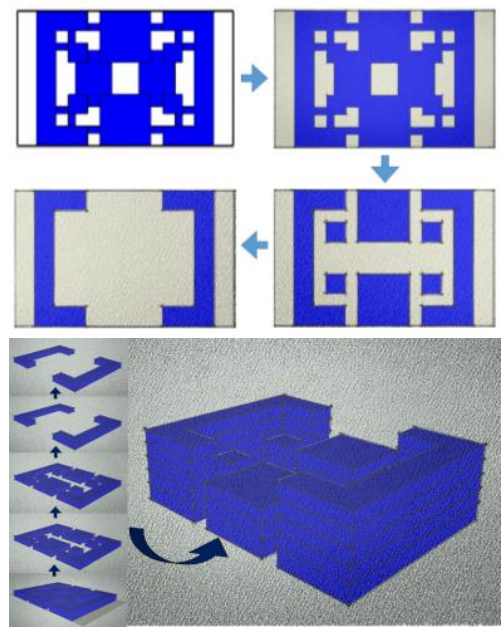

Gambar 10. Proses Bentukan Massa Bangunan Asrama pada Alternatif 1 (Penulis, 2020) 

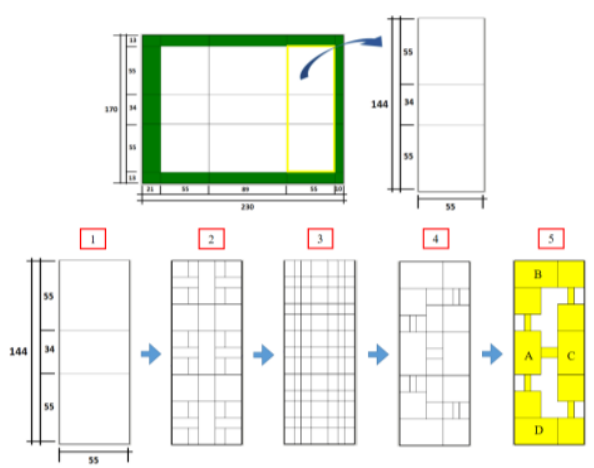

Gambar 11. Proses Transformasi Tapak Area Bangunan Pendidikan pada Alternatif 1 (Penulis, 2020)

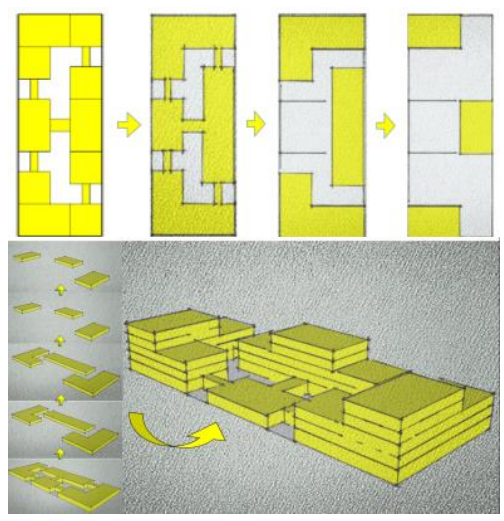

Gambar 12. Proses Bentukan Massa Bangunan Pendidikan pada Alternatif Desain 1 (Penulis, 2020)

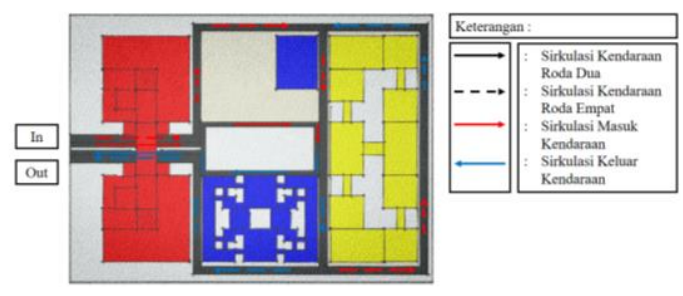

Gambar 13. Sirkulasi Kendaraan pada Alternatif 1 (Penulis, 2020)

Setelah dilakukan transformasi bentuk tapak dan bentukan massa antar zonasi, tahap selanjutnya menggabungkan keseluruhan transformasi bentuk tersebut kedalam tapak, kemudian dibuat jalur sirkulasi pada tapak (lihat Gambar 13).

Pada perletakan zona kelompok bangunan publik, selain memudahkan akses pengguna publik, bangunan ini juga menjadi gerbang akses keluar-masuk area Sekolah Tinggi Desain di Pekanbaru. Bagian tengah tapak yang ditandai warna putih, dapat dijadikan area taman maupun parkir kendaraan (lihat Gambar 14). Bagian ini juga tidak diberikan bangunan, agar bangunan pendidikan yang merupakan bangunan utama, dapat terlihat secara jelas saat memasuki area kompleks Sekolah Tinggi Desain di Pekanbaru. Bentuk bangunan sesuai dengan pendekatan De Stijl yang menggunakan bentukan geometris, serta batasan antar kelompok bangunan yang menggunakan garis linear.

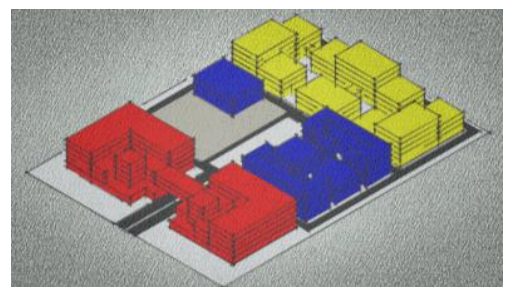

Gambar 14. Penggabungan Keseluruhan Massa Bangunan pada Alternatif 1 (Penulis, 2020)

\section{B. Alternatif Desain 2}

Alternatif desain 2 ini cukup berbeda dari alternatif desain 1, dari segi bentuk maupun posisi zona kelompok bangunan. Akan tetapi, penggunaan warna primer seperti merah, kuning, dan biru (lihat Gambar 15) tetap melambangkan kelompok bangunan publik, kelompok bangunan pendidikan sekolah tinggi desain, serta kelompok asrama mahasiswa dan area penunjang yang sesuai dengan prinsip De Stijl.

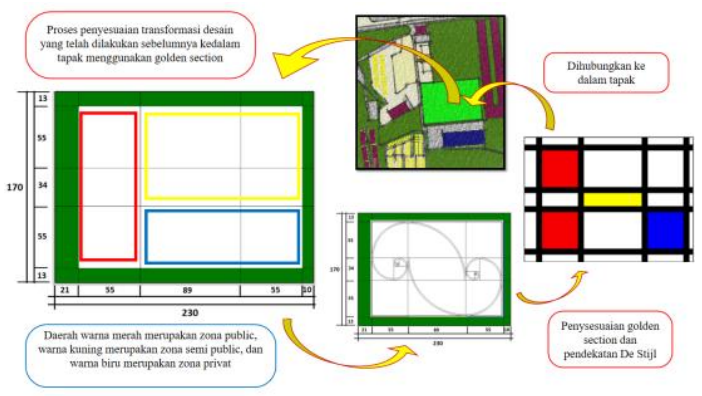

Gambar 15. Penyesuaian konsep tapak terhadap Pendekatan De Stijl pada Alternatif 2 (Penulis, 2020)

Pada alternatif desain 2 ini, kelompok bangunan publik terletak pada bagian barat tapak, tepatnya berada didekat jalan utama agar memudahkan akses bagi pengguna publik. Kelompok bangunan pendidikan terletak pada daerah utara tapak, sedangkan kelompok bangunan asrama mahasiswa terletak pada bagian selatan tapak. Kemudian dilakukan transformasi bentuk tapak sampai bentukan massa pada antar zonasi kelompok bangunan. 


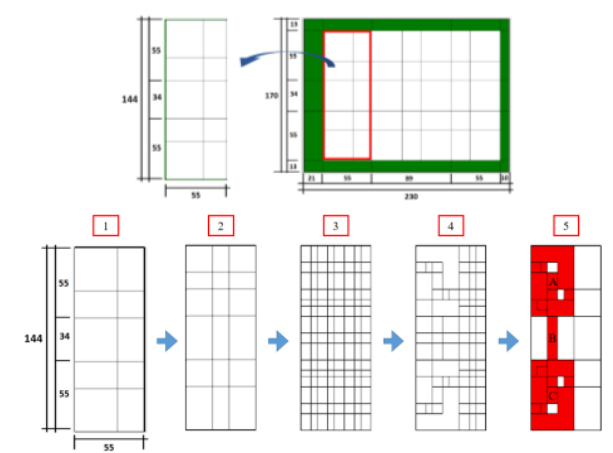

Gambar 16. Proses Transformasi Tapak Bangunan Publik pada Alternatif 2 (Penulis, 2020)

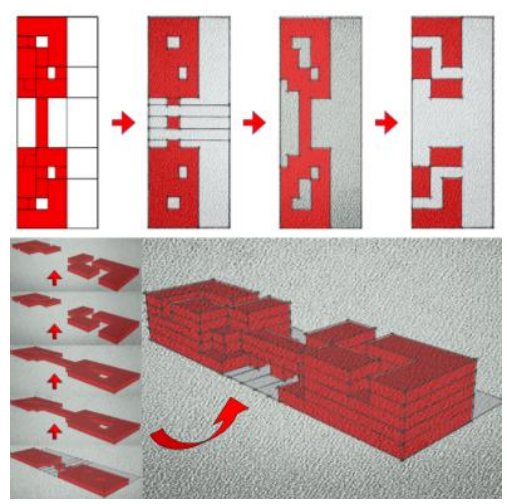

Gambar 17. Proses Bentukan Massa Bangunan Publik pada Alternatif 2 (Penulis, 2020)
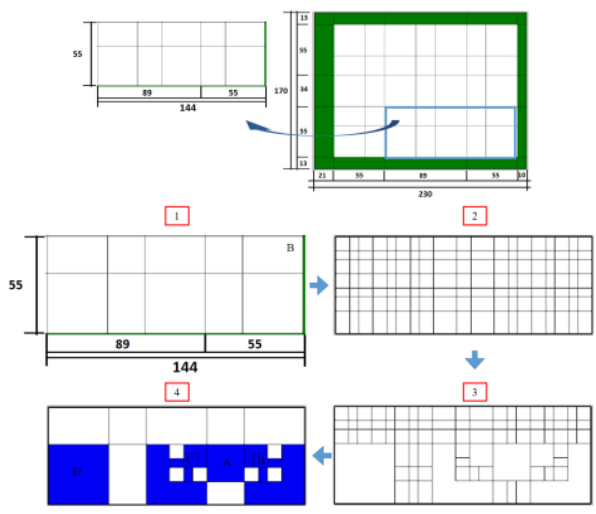

Gambar 18. Proses Transformasi Tapak Area Asrama Mahasiswa pada Alternatif 2 (Penulis, 2020)

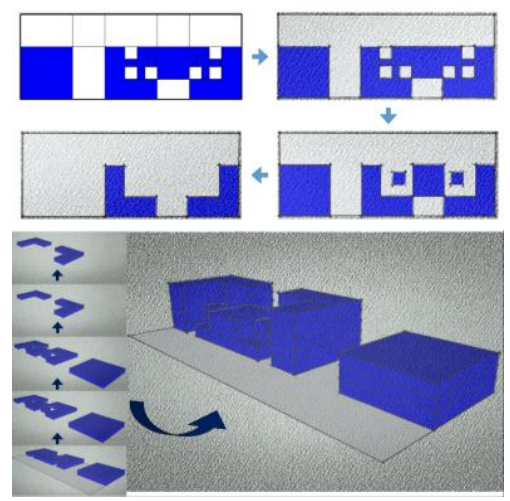

Gambar 19. Proses Bentukan Massa Bangunan Asrama pada Alternatif 2 (Penulis, 2020)
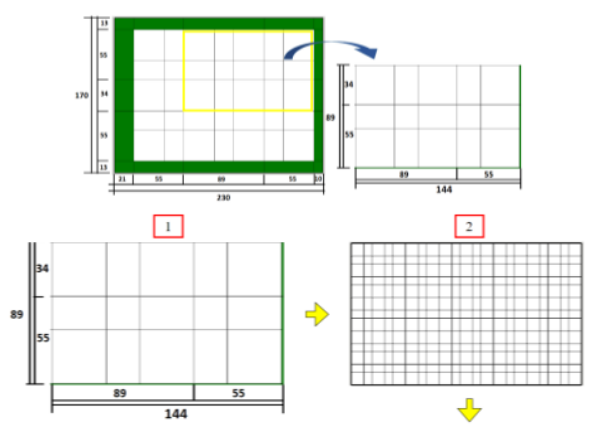

4
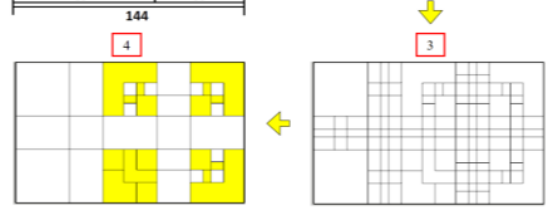

Gambar 20. Proses Transformasi Tapak Area Bangunan Pendidikan pada Alternatif 2 (Penulis, 2020)

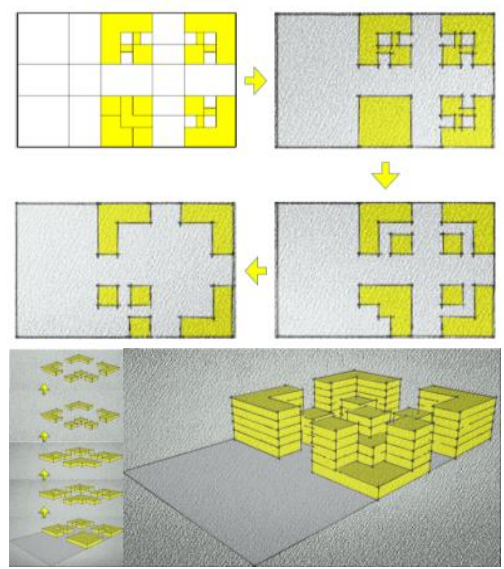

Gambar 21. Proses Bentukan Massa Bangunan Pendidikan pada Alternatif Desain 2 (Penulis, 2020) 


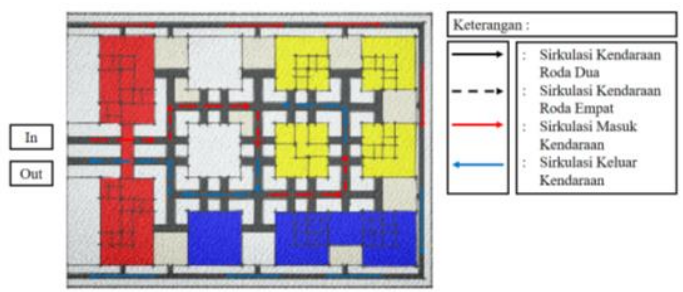

Gambar 22. Sirkulasi Kendaraan pada Alternatif 2 (Penulis, 2020)

Setelah dilakukan transformasi bentuk tapak dan bentukan massa antar zonasi, tahap selanjutnya menggabungkan keseluruhan transformasi bentuk tersebut kedalam tapak, kemudian dibuat jalur sirkulasi pada tapak (lihat Gambar 22). Pada perletakan zona kelompok bangunan publik, selain memudahkan akses pengguna publik, bangunan ini juga menjadi gerbang akses keluar-masuk area Sekolah Tinggi Desain di Pekanbaru. Akses keluar-masuk antara pengguna kendaraan roda dua dengan kendaraan roda empat dibedakan. Akses keluar-masuk pengguna kendaraan roda dua melalui jalur samping bangunan publik, sedangkan pengguna kendaraan roda empat melalui jalur tengah bangunan publik.

Bentuk massa bangunan pada alternatif desain 2 ini cukup berbeda dari alternatif desain 1. Massa bangunan pada alternatif desain 1 cukup dimaksimalkan pada tapak, sehingga cukup dapat memenuhi kebutuhan ruang dalam bangunan dibanding alternatif desain 2 (lihat Gambar 23). Akan tetapi, dari segi kebutuhan ruang outdoor, sirkulasi, vegetasi, penghawaan, dan pencahayaan, alternatif desain 2 ini dapat dikatakan lebih maksimal dikarenakan memiliki jarak antar bangunan yang cukup lebar.

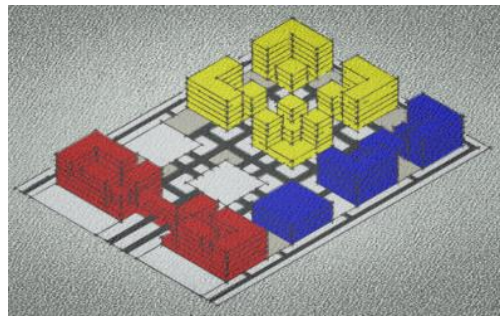

Gambar 23. Penggabungan Keseluruhan Massa Bangunan pada Alternatif 2 (Penulis, 2020)

Seperti halnya dengan alternatif desain 1 , bagian tengah tapak pada alternatif desain 2 yang ditandai warna putih, dapat dijadikan area taman maupun parkir kendaraan. Bagian ini juga tidak diberikan bangunan, agar bangunan pendidikan yang merupakan bangunan utama, dapat terlihat secara jelas saat memasuki area kompleks Sekolah Tinggi Desain di Pekanbaru. Bentuk bangunan sesuai dengan pendekatan De Stijl yang menggunakan bentukan geometris, serta batasan antar kelompok bangunan yang menggunakan garis linear.

\section{Alternatif Desain 3}

Alternatif desain 3 ini dapat dikatakan cenderung mirip dengan alternatif desain 2 dari segi bentuk, namun berbeda dari segi posisi zona kelompok bangunan. Akan tetapi, penggunaan warna primer seperti merah, kuning, dan biru (lihat Gambar 15) tetap melambangkan kelompok bangunan publik, kelompok bangunan pendidikan sekolah tinggi desain, serta kelompok asrama mahasiswa dan area penunjang yang sesuai dengan prinsip De Stijl.

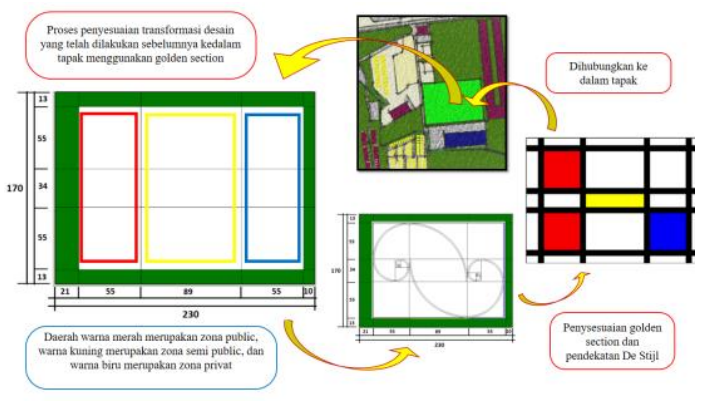

Gambar 24. Penyesuaian konsep tapak terhadap Pendekatan De Stijl pada Alternatif 3 (Penulis, 2020)

Pada alternatif desain 3 ini, kelompok bangunan publik terletak pada bagian barat tapak, tepatnya berada didekat jalan utama. Kelompok bangunan asrama mahasiswa terletak pada bagian timur tapak. Kemudian dilakukan transformasi bentuk tapak sampai bentukan massa pada antar zonasi kelompok bangunan. Transformasi desain pada kelompok bangunan publik pada alternatif desain 3 ini sama seperti alternatif desain 2. Bagian yang berbeda terletak antara area kelompok bangunan pendidikan dengan kelompok bangunan asrama mahasiswa.
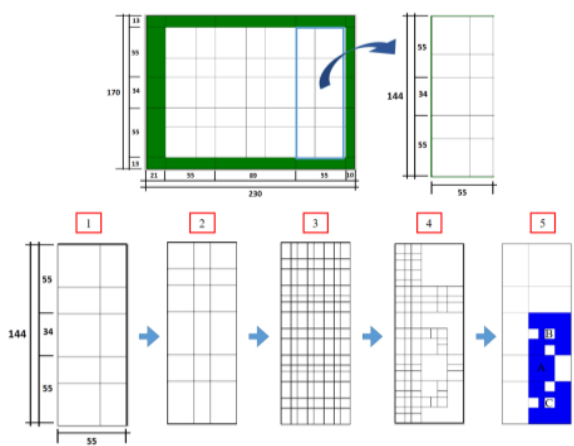

Gambar 25. Proses Transformasi Tapak Area Asrama Mahasiswa pada Alternatif 3 (Penulis, 2020) 


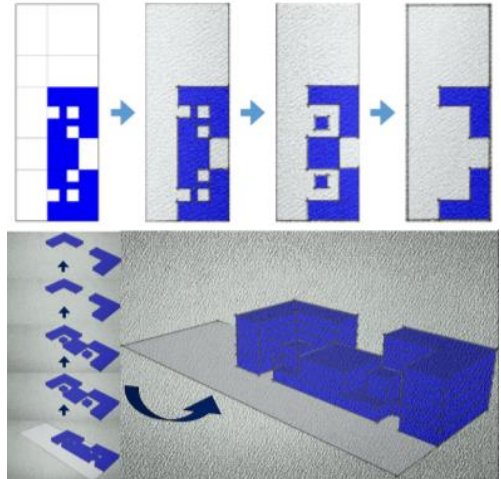

Gambar 26. Proses Bentukan Massa Bangunan Asrama pada Alternatif 3 (Penulis, 2020)

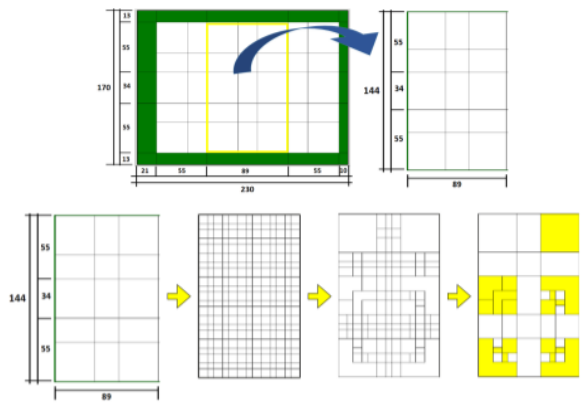

Gambar 27. Proses Transformasi Tapak Area Bangunan Pendidikan pada Alternatif 3 (Penulis, 2020)

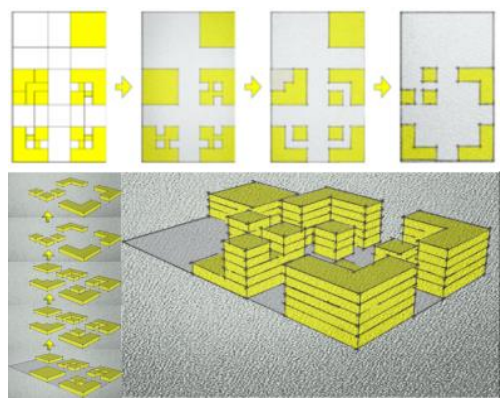

Gambar 28. Proses Bentukan Massa Bangunan Pendidikan pada Alternatif Desain 3 (Penulis, 2020)

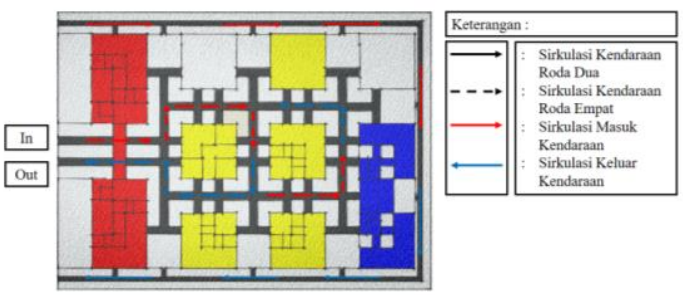

Gambar 29. Sirkulasi Kendaraan pada Alternatif 3 (Penulis, 2020)
Setelah dilakukan transformasi bentuk tapak dan bentukan massa antar zonasi, tahap selanjutnya menggabungkan keseluruhan transformasi bentuk tersebut kedalam tapak, kemudian dibuat jalur sirkulasi pada tapak (lihat Gambar 29). Pada perletakan zona kelompok bangunan publik, selain memudahkan akses pengguna publik, bangunan ini juga menjadi gerbang akses keluar-masuk area Sekolah Tinggi Desain di Pekanbaru. Seperti halnya pada alternatif desain 2, akses keluar-masuk antara pengguna kendaraan roda dua dengan kendaraan roda empat pada alternatif desain 3 ini dibedakan. Akses keluar-masuk pengguna kendaraan roda dua melalui jalur samping bangunan publik, sedangkan pengguna kendaraan roda empat melalui jalur tengah bangunan publik.

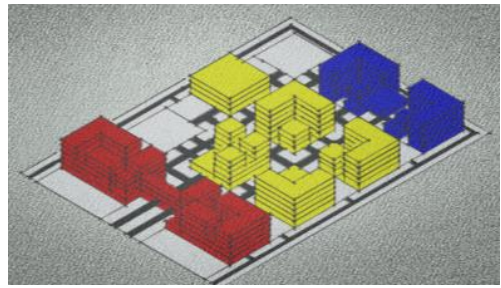

Gambar 30. Penggabungan Keseluruhan Massa Bangunan pada Alternatif 3 (Penulis, 2020)

Bentuk massa bangunan pada alternatif desain 3 ini cukup mirip dengan alternatif desain 2. Dari segi kebutuhan ruang outdoor, sirkulasi, vegetasi, penghawaan, dan pencahayaan, alternatif desain 3 ini dapat dikatakan cukup maksimal dikarenakan memiliki jarak antar bangunan yang cukup lebar (lihat Gambar 30). Perbedaan antara alternatif desain 2 dengan alternatif desain 3 terletak pada posisi zona kelompok bangunan. Bagian kelompok bangunan pendidikan yang merupakan bangunan utama, dapat terlihat secara jelas saat memasuki area kompleks Sekolah Tinggi Desain di Pekanbaru. Kelompok bangunan asrama mahasiswa terletak tersembunyi pada bagian belakang tapak, sehingga area ini sangat tepat dijadikan area privat.

Pada alternatif desain 3 ini, bagian tapak yang ditandai warna putih dapat dijadikan area taman, parkir kendaraan, maupun lapangan olahraga. Bentuk bangunan sesuai dengan pendekatan De Stijl yang menggunakan bentukan geometris, serta batasan antar kelompok bangunan yang menggunakan garis linear.

\section{KESIMPULAN}

Penerapan De Stijl yang telah diterapkan dalam beberapa alternative desain Sekolah Tinggi Desain ini, dirangkum dalam bentuk tabel berikut. 
Tabel 1. Penerapan De Stijl (Penulis, 2020)

\begin{tabular}{|c|c|c|}
\hline No & Penerapan & Penjelasan Prinsip \\
\hline 1 & $\begin{array}{l}\text { Penerapan pada } \\
\text { tapak dan } \\
\text { zonasi } \\
\text { bangunan } \\
\text { bangunan }\end{array}$ & $\begin{array}{l}\text { Pembagian tapak dalam pola } \\
\text { grid, disesuaikan } \\
\text { proporsional } \\
\text { menghasilkan } \\
\text { geometris. }\end{array}$ \\
\hline 2 & $\begin{array}{l}\text { Penerapan pada } \\
\text { eksterior } \\
\text { bangunan }\end{array}$ & $\begin{array}{l}\text { Penggunaan bentukan } \\
\text { geometris, serta penggunaan } \\
\text { garis linear dan perbedaan } \\
\text { dominasi warna primer antar } \\
\text { kelompok bangunan. }\end{array}$ \\
\hline 3 & $\begin{array}{l}\text { Penerapan pada } \\
\text { massa } \\
\text { bangunan }\end{array}$ & $\begin{array}{l}\text { Penggunaan } \\
\text { geometris pada bentukan } \\
\text { ruang yang berasal dari } \\
\text { bentukan dasar persegi dan } \\
\text { persegi panjang menjadi } \\
\text { bentukan kubus serta balok, } \\
\text { yang dapat dilihat juga pada } \\
\text { bagian ketinggian serta } \\
\text { tampak bangunan. }\end{array}$ \\
\hline
\end{tabular}

Perbedaan antar alternative desain ini dapat dirangkum dalam bentuk poin-poin, diantaranya:

1. Pada pembagian zoning kelompok bangunan pada tapak,

2. Pada sirkulasi kendaraan pada tapak,

3. Pada bentukan tapak antar kelompok bangunan, serta

4. Pada bentukan massa antar bangunan.

Pendekatan De Stijl dapat menghasilkan beberapa alternatif desain yang dapat disesuaikan dengan kebutuhan. Penerapan pendekatan ini dapat diterapkan dalam keseluruhan desain, baik pada pembagian penzoningan pada bentuk tapak, bentuk massa serta bagian desain lainnya pada perancangan Sekolah Tinggi Desain di Pekanbaru.

\section{DAFTAR PUSTAKA}

Ching, F. D. (2000). Arsitektur, Bentuk, Ruang dan Tatanan. Jakarta: Erlangga.

Harrison, C. \& Paul W. (2003). Art in Theory 19002000 An Anthology of Changing Ideas. Oxford: Blackwell Publishing.

Kemendikbud. (2013). Standar Nasional Pendidikan Tinggi. Jakarta: Direktorat Jenderal Pendidikan Tinggi.

Kemenristekdikti. (2018). Statistik Pendidikan Tinggi Tahun 2018. Jakarta: Pusdatin Iptek Dikti.

Keppres. (2014). Peraturan Pemerintah RI Nomor 4 tahun 2014 tentang Penyelenggaraan Pendidikan Tinggi dan Pengelolaan Perguruan Tinggi.
Neufert, E. (2002). Data Arsitek Edisi Kedua Jilid 2. Jakarta: Erlangga.

Permendikbud. (2020). Undang-Undang Republik Indonesia Nomor 3 tahun 2020 tentang Standar Nasional Pendidikan Tinggi. Jakarta: Direktorat Jenderal Pendidikan Tinggi

Permendikbud. (2020). Undang-Undang Republik Indonesia Nomor 7 tahun 2020 tentang Pendirian, Perubahan, Pembubaran Perguruan Tinggi Negeri, dan Pendirian, Perubahan, Pencabutan Izin Perguruan Tinggi Swasta. Jakarta: Direktorat Jenderal Pendidikan Tinggi.

Rietveld, G. 1963. Rietveld, 1924. Schröder Huis. Hilversum: Steendrukkerij de Jong.

Sachari, A. (2000). Pengantar Tinjauan Desain. Bandung: ITB.

Xiaoli, F. and Zhiyong D. (2019). 'Study on the Connotation of Holistic Design Associated with De Stijl Architecture and Furniture, E3S Web of Conferences 136, 01032, 1-4. 